London School of Hygiene and Tropical Medicine, London, UK

Cite this as: BMJ2020;370:m2858 http://dx.doi.org/10.1136/bmj.m2858 Published: 17 July 2020

\section{England's PPE procurement failures must never happen again}

Fixing a broken system is an urgent priority ahead of any winter surge in covid-19

\section{Martin McKee professor of European public health}

The British Prime Minister's words were clear. Asked about the way that covid-19 had spread through care homes, he said: "We discovered too many care homes didn't really follow the procedures." 1 The response from those running these homes was fast and furious, with one senior executive describing what was widely perceived as an attempt to blame them for the deaths as "a Kafkaesque alternative reality." We now know that there were several reasons why so many died, including movement of infected staff among different homes and transfer of infected patients from hospitals, but a major factor was the shortage of personal protective equipment (PPE). Quite simply, care homes were unable to get the supplies they needed.

Some problems were inevitable in the early days of the pandemic, as the UK was competing in a global market in which everyone was chasing a limited supply. But mistakes should be opportunities for learning, especially when there is a real risk of a resurgence of covid-19 in the winter. Unfortunately, as a new report from the House of Commons Public Accounts Committee states, "we were not convinced that [the Department of Health and Social Care] was treating the matter with sufficient urgency." It goes on to say that current governance arrangements are unclear and stresses that "it is vital that the same problems do not happen again."”

Procurement is one of those things that few notice until it goes wrong, as it has done on a massive scale in England's covid-19 response. Until the end of the Brexit transition period, it is governed by EU law, which is based on the principles of transparency and value for money. Thus all purchases above a certain value, which varies according to what is being bought by whom, must be advertised, and the successful offer must be the most economically advantageous tender.

However, the reality is much more complicated, especially in healthcare, when it is not always clear exactly what is wanted or how it will fit with existing systems. Consequently, it is possible to work with prospective suppliers to find the best solution, using mechanisms such as an initial competition to identify prospective suppliers followed by negotiation or dialogue. In an emergency it is also possible, with important safeguards, to purchase things without prior publication. But this brings certain risks.

\section{Repeated mistakes}

Numerous accounts of procurement failures have emerged across Europe during the current pandemic. Health authorities entered into contracts with companies that promised much but failed to deliver, and what they did supply was often substandard. In some cases certification documents were issued without checks or were forged. ${ }^{3} \mathrm{~A}$ few seem to have involved corruption or organised crime. ${ }^{45}$ Yet often it was just that mistakes were made. Hard pressed procurement staff failed to do the most basic due diligence procedures, such as checking whether the company had filed accounts, had assets, or had any experience in what it claimed it could do.

Of course, procurement failures are familiar to observers of the UK. This is a country that has repeatedly outsourced important tasks, such as security at the Olympic Games or probation services, only to see them fail. ${ }^{6}$ Memorably, it awarded a multimillion pound contract for sea transport to a company with no ships, which promised to sail into a port with no suitable facilities, and with documentation that seemed to have been adapted from a pizza delivery company. ${ }^{7}$ Hence, it should be no surprise that it has provided some of the worst examples of failures to procure PPE, ${ }^{8} 9$ along with tests ${ }^{1011}$ and ventilators. ${ }^{12}$ It has also done so in the glare of publicity, as when ministers promised at the daily press briefings that a consignment of PPE from Turkey was on its way, with Royal Air Force planes ready to collect it; $10 \%$ of the order arrived, several days late, when it was found to be unusable. ${ }^{13}$

The problems experienced with procurement, and the lack of confidence by the Public Accounts Committee that procedures have been fixed, highlight the importance of a rapid review of the UK's covid-19 response. ${ }^{14}$ However, this has now become urgent. Buried in the documents accompanying the Chancellor of the Exchequer's summer statement is a commitment to spend over €15bn ( $€ 16 \mathrm{bn} ; \$ 19 \mathrm{bn}$ ) on PPE for frontline staff. ${ }^{15}$ Yet that money risks being wasted if the same procurement mistakes are repeated.

Looking ahead, there are even greater concerns. Once the UK's Brexit transition arrangements come to an end, it will no longer be subject to the safeguards that, however imperfectly they have been enforced, still exist. Dominic Cummings, the Prime Minister's chief adviser, has signalled his desire to be freed from such controls. ${ }^{3}$ There are already questions about transparency surrounding recent government contracts for services in the area of artificial intelligence, something that Cummings has long championed but which has given rise to considerable concern. ${ }^{16}$ Is this really a good time to make it even more difficult to know what our money is being spent on?

Competing interests: I have read and understood BMJ policy on declaration of interests and declare that I am a member of Independent SAGE and the European Commission's expert panel on effective ways of investing in health, where I am co-rapporteur on a forthcoming report on procurement in the health sector. 
1 Walker P, Syal R, Stewart H. Boris Johnson under pressure to apologise for care home "insult." Guardian; 2020 Jul 7. https://www.theguardian.com/society/2020/jul/07/care-home-chief-denounces-clumsy-and-cowardly-boris-johnson-comments

2 Public Accounts Committee. NHS capital expenditure and financial management: House of Commons, 2020. https://publications.parliament.uk/pa/cm5801/cmselect/cmpubacc/344/34402.htm

3 Cummings D. On the referendum \#31: Project Maven, procurement, lollapalooza results \& nuclear/AGI safety: Word Press, 2019. https://dominiccummings.com/2019/03/01/on-the-referendum-31-project-maven-procurement-lollapalooza-results-nuclear-agi-safety/

4 Europol. Corona crimes: suspect behind $€ 6$ million face masks and hand sanitisers scam arrested thanks to international police cooperation. Press release, 6 Apr 2020. https://www.europol.europa.eu/newsroom/news/corona-crimes-suspect-behind-€6-million-face-masks-and-hand-sanitisers-scam-arrested-thanks-to-international-police-cooperation

5 Bauldry J. Belgium investigates deal with Lux mask provider. Delano.lu, 22 May 2020 https://delano.lu/d/detail/news/belgium-investigates-deal-lux-mask-provider/210834

6 Institute for Government. Government outsourcing 2018. https://www.instituteforgovernment.org.uk/our-work/policy-making/government-outsourcing

7 Quinn B. Brexit freight ferry firm appears all geared up-to deliver pizzas. Guardian 2019 Jan 3. https://www.theguardian.com/politics/2019/jan/03/brexit-freight-ferry-firm-appears-all-gearedup-to-deliver-pizzas

8 Davies H. Private firm running UK PPE stockpile was sold in middle of pandemic. Guardian 2020 Apr 22. https://www.theguardian.com/world/2020/apr/22/revealed-private-firm-running-uk-ppestockpile-was-sold-in-middle-of-pandemic

9 Geoghegan P, Hoskins M. “Useless” Deloitte accused of PPE failings amid COVID-19 deal secrecy. Open Democracy 2020. https://www.opendemocracy.net/en/dark-money-investigations/uselessdeloitte-accused-of-ppe-failings-amid-covid-19-deal-secrecy/

10 Devlin H. Coronavirus "game changer" testing kits could be unreliable, UK scientists say. Guardian 2020 Apr 5. https:/www.theguardian.com/world/2020/apr/05/coronavirus-testing-kits-couldbe-unreliable-uk-scientists-say

11 Kirkpatrick D, Bradley J. UK paid $\$ 20$ million for new coronavirus tests. They didn’t work. New York Times; 2020 [updated 20200416. Available from: https://www.nytimes.com/2020/04/16/world/europe/coronavirus-antibody-test-uk.html

12 Foster P. Medical experts warned UK watchdog against "basic" ventilator drive. Financial Times 2020 Jun 23. https://www.ft.com/content/a4574c5c-52f2-4c28-91ef-cd0a0ea2bb9b

13 Mason R. Government confirms 400,000 Turkish gowns are useless for NHS. Guardian 2020 May 7. https://www.theguardian.com/world/2020/may/07/government-confirms-400000turkish-gowns-are-useless-for-nhs

14 McKee M, Gill M, Wollaston S. Public inquiry into UK's response to covid-19. BMJ 2020;369:m2052. doi: 10.1136/bmj.m2052 pmid: 32444349

15 Treasury HM. Plan for jobs. 2020. https://assets.publishing.service.gov.uk/government/uploads/system/uploads/attachment_data/file/898421/A_Plan_for_Jobs_WWeb_.pdf

16 Evans R, Pegg D. Vote Leave Al firm wins seven government contracts in 18 months. Guardian 2020 May 4. https://www.theguardian.com/world/2020/may/04/vote-leave-ai-firm-wins-sevengovernment-contracts-in-18-months

This article is made freely available for use in accordance with BMJ's website terms and conditions for the duration of the covid-19 pandemic or until otherwise determined by BMJ. You may use, download and print the article for any lawful, non-commercial purpose (including text and data mining) provided that all copyright notices and trade marks are retained. 